\title{
Antimicrobial evaluation of various leaves extracted samples of nettle desert (Forsskaolea tenacissima L.)
}

\author{
Tariq Aslam ${ }^{1}$, Syed Sadaqat Shah ${ }^{1,2}$, Sajjad Ahmed ${ }^{1,3}$, Nazim Hassan ${ }^{4}$, \\ Mu Peng ${ }^{5}$, Saddam Hussain ${ }^{1,3}$ and Zhijian $\mathrm{Li}^{2 *}$ \\ 1. Department of Botany, Islamia College Peshawar, KPK, Pakistan \\ 2. Key Laboratory of Vegetation Ecology, Ministry of Education, Institute of Grassland Science, School of Life \\ Science, Northeast Normal University, Changchun 130024, China \\ 3. Key Laboratory of Molecular Epigenetics of Ministry of Education, School of Life Science, Northeast Normal \\ University, Jilin, 130024, PR. China \\ 4. Institute of Grassland Science, Northeast Normal University, and Key Laboratory of Vegetation Ecology, \\ Ministry of Education, Changchun, Jilin 130024 China \\ 5. College of Life Science, Northeast Forestry University, Jilin, China \\ *Corresponding author's email: khankhanafridi10@yahoo.com \\ Citation \\ Tariq Aslam, Syed Sadaqat Shah, Sajjad Ahmed, Nazim Hassan, Mu Peng, Saddam Hussain and Zhijian Li. \\ Antimicrobial evaluation of various leaves extracted samples of nettle desert (Forsskaolea tenacissima L.). Pure and \\ Applied Biology. Vol. 7, Issue 1, pp152-159. http://dx.doi.org/10.19045/bspab.2018.70018 \\ \begin{tabular}{llll}
\hline \hline Received: 30/10/2017 & Revised: 04/01/2018 & Accepted: 05/01/2018 & Online First: 17/01/2018 \\
\hline \hline
\end{tabular}
}

\section{Abstract}

The present study evaluates the anti-microbial activity of three different crude extracts (ethanol, aqueous and n-hexane) of Forsskaolea tenacissima L. leaves against gram negative and gram positive bacteria and fungi using well diffusion method. N-hexane extract showed tremendous inhibition of $12 \mathrm{~mm}(80 \% \mathrm{ZI})$ and $10 \mathrm{~mm}(71.42 \% \mathrm{ZI})$ against Staphylococcus aureus and Bacillus subtillis at $1000 \mu \mathrm{g} / \mathrm{ml}$ concentration. Similarly, aqueous extract at the concentration of 1000 $\mu \mathrm{g} / \mathrm{ml}$ reduced the growth of Xanthomonas maltophilia and Escherichia coli as $11 \mathrm{~mm}(68.75 \%$ ZI) and $9 \mathrm{~mm}(60.00 \%)$, respectively. However, ethanol extract showed good activity of $12 \mathrm{~mm}$ (75.00\%) against Clavibacter michiganense Aqueous extract showed 9mm (75.00\%) against Acromonium alternatum at $1000 \mu \mathrm{g} / \mathrm{ml}$. Rhizopus stolinifer and Trichoderma reesei both were found sensitive to aqueous extract, which showed 11 and $8 \mathrm{~mm}(68.75$ and $57.14 \% \mathrm{ZI})$ at 1000 $\mu \mathrm{g} / \mathrm{ml}$ concentration, respectively. The growth of Aspergillus niger was inhibited by ethanol extract through $9 \mathrm{~mm}(56.25 \% \mathrm{ZI})$ at the concentration of $1000 \mu \mathrm{g} / \mathrm{ml}$. The above study determined the medicinal importance of Forsskaolea tenacissima.

Keywords: Antimicrobial activity; Bacteria; Forsskaolea tenacissima; Well diffusion method

\section{Introduction}

In developed countries, about $80 \%$ of plants are used as traditional medicines that serve as excellent sources of compounds (drugs). The plants are collected for the properties they exhibit such as the synthesis of secondary product [1], and inhibitory effect against various growing human [2]. Traditional medicines are being used for practices, knowledge and also need for making of better plants and animal-based approaches [1, 3]. The use of natural medicine and local 
practices are common in the treatment of various diseases [4]. An increase in number of infectious agents with strong resistance to commercial antimicrobial compounds has been noticed [5]. Due to this reason, the secondary product produced by medicinal plant is of excellent value due to its antimicrobial constituents [6]. These antimicrobial agents mark the most important discovery of 20 century in the field of medicine [7]. Also, traditional medicines system is now well popular and adopted at global level as a primary health care system [8].

Main resources for modern drugs are from Mother Nature. According to World Health Organization (WHO) reports, the use of traditional medicine in the $1^{\text {st }}$ world countries is at peak. Failure of conventional medicine that can cure chronic diseases, emergence of multi-drug resistance pathogens and parasites, adverse effects of chemical drugs and increasing cost are some of the reasons that made traditional medicines using again by people [9].

The plants serve as an essential source of new chemicals with potential therapeutic effects [10]. In recent times, several infectious diseases mostly caused by fungal and bacterial pathogens are treated by antibiotics [11]. It is believed that chemical classes such as sterols, alkaloids, glycosides, flavonoids, tannins and carbohydrates are more preferred natural antibiotics due to their antimicrobial activity [12]. Developed countries have improved the use of herbal medicine as the alternative solution to health problems and cost of pharmaceutical products. Human pathogens have gained drugs resistance against commonly used antibiotics there by developing immunity to them. However, plants have got cure to infectious as well as chronic diseases [13].

Local communities have been using medicinal plants for centuries [14]. In Pakistan, 6000 species of higher plants are reported. Out of these reported 6000 species, $12 \%$ are used medicinally $[14,15]$. Ethno botanical studies have documented local knowledge about the use of plants as a drug in ailment treatment [16]. Ethno botany by providing useful knowledge regarding medicinal plants saves money and time [17]. Through ethno botanical census, knowledge regarding local plants and their use in the treatment of various diseases has been documented as a mean to provide insight for the production of new drugs against infection causing diseases [14]. Dissimilar plant parts are employed for the physiotherapy of several kinds of sicknesses and infections [18]. Medicinal plants can provide alternative treatment minor infectious diseases [19].

Forsskaolea tenacissima is a member of nettle genus. It is found in sandy clay gravelly soils of arid and semi-arid waste lands up to 1,200 meters (3,900 ft) like Mediterranean woodlands and shrub lands, semi-steppe, shrub-steppes, modest to extreme deserts [20] Forsskaolea tenacissima is highly resistance to drought and salinity [21], it is noncultivated species found in low rain area in sandy and stony soil where no or less water is found.

Forsskaolea tenacissima have already been screened for possible anti-hypertensive, spasmogenic and spasmolytic activity [22]. It belongs to family Utricaceae which consist of 45 genera spread in tropical and subtropical region of the world [8]. Medicinal and commercial importance of this family is wide, its plants are known to be galactagogue [24], antiviral [23] and anti-inflammatory [25]. Urticadioica is used in benign pro-static hyperplasia and also as libido stimulant, digestive disorder, kidney problems, respiratory, diabetes and excessive menstrual bleeding [26]. Present study aimed at evaluating antimicrobial activity of Forsskaolea tenacissima L. against different human pathogens. 
Materials and methods

Experiments regarding this study were conducted in research Laboratory of Department of Botany, Islamia College University Peshawar, Pakistan.

\section{Plant materials}

Forsskaolea tenacissima leaves were collected from Jarjorey F-R Peshawar Tribal area. The leaves were subjected to room temperature and shade for a period of 3 month to completely dry. An ordinary grinder was used to grind the leaves.

\section{Preparation of crude extract}

About $70 \mathrm{~g}$ of ground plant powder was taken three times in three round bottom flasks, first round bottom flask ethanol to the second nhexane and to $3^{\text {rd }}$ round bottom flask distal water was added. After 24 hours, the filtrate was filtered with cotton and the process was repeated 3 times. The concentration of the extracts was performed by rotary evaporator at $60^{\circ} \mathrm{C}$. The material was again dried through water bath at $55^{\circ} \mathrm{C}$ and was stored in bottles.

\section{Microorganisms used}

Gram -ve (Escherichia coli and Xanthomonas maltophilia), Gram +ve (Bacillus subtilis, Clavibacter michiganense and Staphylococcus aureus) bacteria and fungus (Aspergillus niger, Trichoderma reesei, Rhizopus stolinifer and Acromonium alternatum) were obtain from Institute of Biotechnology and genetic Engineering, University of Agriculture, Peshawar, KPK Pakistan.

\section{Well diffusion susceptibility method}

Well diffusion method was used to study antimicrobial activity of different plant extract. Fungal culture was grown on PDA while bacterial cultural were grown on agar media as mentioned by [27]. For the purpose to know antimicrobial activity of the species, petri plates impregnated with microbes were added with the extracts obtained from the plant with dissimilar concentration such as $500 \mu \mathrm{g}$ and $1000 \mu \mathrm{g}$ into holes present in media. The bacterial culture incubated at $37^{\circ} \mathrm{C}$ for 24 hours and fungal cultural were incubated at $37^{\circ} \mathrm{C}$ for 3 Days.

\section{Antimicrobial activity bioassay}

To determine antibacterial activity, specific amount of nutrient agar was mixed in sterilized distal water contained in bottle. All the experimental apparatus such as petri plates, borer and liquid media were sterilized at the pressure of $1.5 \mathrm{lbs}$ and $121^{\circ} \mathrm{C}$ for fifteen to twenty minutes. Then the agar was poured in petri plates in sterilized environment and the agar was allowed to solidify. A sterilized borer was used to make holes in the media.

For antifungal activity, the same procedure was used except the nutrient agar media. In antifungal activity, PDA media was used instead of nutrient agar. But the procedure was same as antibacterial activity.

\section{Applying antifungal test}

For antifungal activity require amount of Potato Dextrose Agar (PDA) media (14.25 gm in $400 \mathrm{ml}$ of distal water) was prepared for 12 petri plates. The media was prepared in bottle. The media and all the apparatus used in this experiment were sterilized in autoclave for 20 minutes at $1.5 \mathrm{lbs}$ of pressure and $121^{\circ} \mathrm{C}$ temperatures. Later, the sterilized media was poured in sterilized petri plates in laminar flow hood and allow it to solidify in petri plates and made 3 holes in each petri plates through sterilized borer. To avoid contamination all the procedure was attempted inside the laminar flow hood.

After formation of holes the fungus was applied by streaking with sterile inoculation loop on the PDA media plates in a laminar flow. When streaking was completed, plant extract was then added and antibiotic at different concentration. An in first hole 1000 $\mu \mathrm{g} / \mathrm{ml}$ of plant extract was added and in second hole $500 \mu \mathrm{g} / \mathrm{ml}$ of plant extract was added while in last hole standard antifungal against fungi was added. After that the petri plates were closed and shifted from laminar 
flow hood to incubator and kept in incubator at $37^{\circ} \mathrm{C}$ for 3 days.

Zone of inhibition around each hole for antifungal potential was recorded after three days.

Positive control used against fungal strains $0.05 \%$ Flumetazole was used as a positive control.

\section{Statistics}

Simple statistics was used as the mean values were converted in percent via the following formula.

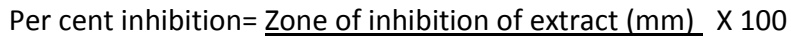
Zone of inhibition of standard $(\mathrm{mm})$

\section{Results}

The present work was conducted on three different crude extracts (ethanol, n-hexane and aqueous) of Forsskaolea tenacissima (leaves) against gram positive and gram negative bacteria. The result revealed that ethanol extract of Forsskaolea tenacissima against Staphylococcus aureus showed 8 $(53.35 \%)$ and $10(66.66 \%) \mathrm{mm}$ zone of inhibition (ZI) in concentration of 500 and $1000 \mu \mathrm{g} / \mathrm{ml}$. The $\mathrm{n}$-hexane extract showed $10 \mathrm{~mm}$ and $12 \mathrm{~mm}$ zone of inhibition at concentration of $500 \mu \mathrm{g} / \mathrm{ml}$ and $1000 \mu \mathrm{g} / \mathrm{ml}$, (66.66 and 80\%) respectively. Against Bacillus subtilis the ethanol extract reduced the growth by $6 \mathrm{~mm} \quad(42.75 \% \quad \mathrm{ZI})$ at concentration of $500 \mu \mathrm{g} / \mathrm{ml}$ and $8 \mathrm{~mm}$ $(57.14 \% \mathrm{ZI})$ at concentration of $1000 \mu \mathrm{g} / \mathrm{ml}$, respectively. The n-hexane extract inhibited the growth of Bacillus subtilis by $7 \mathrm{~mm}(50 \%$ $\mathrm{ZI})$ at concentration of $500 \mu \mathrm{g} / \mathrm{ml}$ and $10 \mathrm{~mm}$ (71.42 ZI) at concentration of $1000 \mu \mathrm{g} / \mathrm{ml}$, respectively.

Against Xanthomonas maltophilia, highest zone of inhibition was recorded by aqueous extract at the concentration of 500 and 1000 $\mu \mathrm{g} / \mathrm{ml}$, which showed 9 and $11 \mathrm{~mm}$ (56.25 and $68.75 \%$ ZI), respectively. The ethanol extracted sample showed $7 \mathrm{~mm}(43.75 \% \mathrm{ZI})$ at concentration of $500 \mu \mathrm{g} / \mathrm{ml}$ and $9 \mathrm{~mm}$ $(56.25 \% \mathrm{ZI})$ at concentration of $1000 \mu \mathrm{g} / \mathrm{ml}$, respectively. Against Escherichia coli highest zone of inhibition was recorded by aqueous extract, as $9 \mathrm{~mm}(60 \% \mathrm{ZI})$ at the concentration of $1000 \mu \mathrm{g} / \mathrm{ml}$, while lowest zone of inhibition was recorded by $\mathrm{N}$-hexane as $5 \mathrm{~mm}(33.33 \% \mathrm{ZI})$, at the concentration of $500 \mu \mathrm{g} / \mathrm{ml}$. Ethanol extracted sample showed 6 and $7 \mathrm{~mm}$ (40 and $46.66 \% \mathrm{ZI}$ ) at the concentration of 500 and $1000 \mu \mathrm{g} / \mathrm{ml}$, respectively. Against Clavibacter michiganense all samples were effective and showed reliable results. The highest zone was recorded ethanol extract which was 8 and $12 \mathrm{~mm}(50$ and $75 \% \mathrm{ZI})$ at the concentration of $500 \mu \mathrm{g} / \mathrm{ml}$ and $1000 \mu \mathrm{g} / \mathrm{ml}$, respectively. While n-hexane extracted sample displayed lowest ZI of $7 \mathrm{~mm}$ and $9 \mathrm{~mm}$ (43.75 and $56.25 \% \mathrm{ZI})$ at the concentration of 500 and $1000 \mu \mathrm{g} / \mathrm{ml}$, respectively.

The antifungal activity of ethanol, n-hexane and aqueous extracts of Forsskaolea tenacissima leaves against Acromonium alternatum have been shown in table 1 . The aqueous extract showed 7 and 9mm (58.33 and $75 \% \mathrm{ZI}$ ) at the concentration of 500 and $1000 \mu \mathrm{g} / \mathrm{ml}$, respectively. The lowest ZI was recorded by n-hexane extract as $5 \mathrm{~mm}$ $(41.66 \% \mathrm{ZI})$ at the concentration of 500 $\mu \mathrm{g} / \mathrm{ml}$. Against Rhizopus stolinifer the aqueous extract inhibited the growth by 9 and $11 \mathrm{~mm}(56.25$ and $68.75 \% \quad \mathrm{ZI})$ at the concentration of 500 and $1000 \mu \mathrm{g} / \mathrm{ml}$, respectively. The ethanol and n-hexane extracts showed 8 and $9 \mathrm{~mm}$ (50 and $56.25 \%$ ZI) at higher concentration.

Data regarding antifungal activity is shown in table 1. Results revealed that Trichoderma reesei was highly inhibited by ethanol and aqueous at higher concentration. The data was recorded as $8 \mathrm{~mm}(57.14 \% \mathrm{ZI})$ at the concentration of $1000 \mu \mathrm{g} / \mathrm{ml}$. The antifungal activity of ethanol, n-hexane and aqueous extracted sample from Forsskaolea tenacissima leaves against Aspergillus niger is shown in table 1. Aspergillus niger was highly sensitive to ethanol extract, which 
showed 9 and $7 \mathrm{~mm}(43.75$ and $56.25 \% \mathrm{ZI})$ at the concentration of 500 and $1000 \mu \mathrm{g} / \mathrm{ml}$, respectively. Our data also revealed that Aspergillus niger was susceptible to the n- hexane extract, which showed shown 5 and $7 \mathrm{~mm}(31.2543 .75 \% \mathrm{ZI})$ at the concentration of 500 and $1000 \mu \mathrm{g} / \mathrm{ml}$, respectively.

Table 1. Antimicrobial activities of leaves extracts of nettle desert (Forsskaolea tenacissima L.) against different human pathogenic microorganisms by well diffusion method

\begin{tabular}{|c|c|c|c|c|c|c|c|c|}
\hline \multirow[t]{2}{*}{ Organisms } & \multirow[t]{2}{*}{$\begin{array}{l}\text { Conc. } \\
\mu \mathrm{g} / \mathrm{ml}\end{array}$} & \multicolumn{3}{|c|}{$\begin{array}{c}\text { Mean diameter of zones of } \\
\text { inhibition }(\mathrm{mm})\end{array}$} & \multicolumn{3}{|c|}{ Percent zone of inhibition (\%) } & \multirow{2}{*}{$\begin{array}{c}\text { Positive } \\
\text { control } \\
\text { Ciprofloxacin }\end{array}$} \\
\hline & & Ethanol & $\begin{array}{c}\mathrm{N}- \\
\text { hexane }\end{array}$ & Aqueous & Ethanol & $\begin{array}{c}\mathrm{N}- \\
\text { hexane }\end{array}$ & Aqueous & \\
\hline \multirow{2}{*}{$\begin{array}{c}\text { Staphylococcus } \\
\text { aureus }\end{array}$} & 500 & 8 & 10 & 7 & 53.33 & 66.66 & 46.66 & \multirow[t]{2}{*}{15} \\
\hline & 1000 & 10 & 12 & 8 & 66.66 & 80.00 & 53.33 & \\
\hline \multirow[t]{2}{*}{ Bacillus subtilis } & 500 & 6 & 7 & 7 & 42.85 & 50.00 & 50.00 & \multirow[t]{2}{*}{14} \\
\hline & 1000 & 8 & 10 & 9 & 57.14 & 71.42 & 64.28 & \\
\hline \multirow{2}{*}{$\begin{array}{l}\text { Xanthomonas } \\
\text { maltophilia }\end{array}$} & 500 & 7 & 8 & 9 & 43.75 & 50.00 & 56.25 & \multirow[t]{2}{*}{16} \\
\hline & 1000 & 9 & 10 & 11 & 56.25 & 62.50 & 68.75 & \\
\hline \multirow[t]{2}{*}{ Escherichia coli } & 500 & 6 & 5 & 7 & 40.00 & 33.33 & 46.66 & \multirow[t]{2}{*}{15} \\
\hline & 1000 & 7 & 6 & 9 & 46.66 & 40.00 & 60.00 & \\
\hline \multirow{2}{*}{$\begin{array}{l}\text { Clavibacter } \\
\text { michiganense }\end{array}$} & 500 & 8 & 7 & 8 & 50.00 & 43.75 & 50.00 & \multirow[t]{2}{*}{16} \\
\hline & 1000 & 12 & 9 & 10 & 75.00 & 56.25 & 62.5 & \\
\hline \multirow{2}{*}{$\begin{array}{c}\text { Acromonium } \\
\text { alternatum }\end{array}$} & 500 & 7 & 5 & 7 & 58.33 & 41.66 & 58.33 & \multirow[t]{2}{*}{12} \\
\hline & 1000 & 8 & 6 & 9 & 66.66 & 50.00 & 75.00 & \\
\hline \multirow{2}{*}{$\begin{array}{l}\text { Rhizopus } \\
\text { stolinifer }\end{array}$} & 500 & 7 & 7 & 9 & 43.75 & 43.75 & 56.25 & \multirow[t]{2}{*}{16} \\
\hline & 1000 & 8 & 9 & 11 & 50.00 & 56.25 & 68.75 & \\
\hline \multirow{2}{*}{$\begin{array}{c}\text { Trichoderma } \\
\text { reesei }\end{array}$} & 500 & 6 & 5 & 7 & 42.85 & 35.71 & 50.00 & \multirow[t]{2}{*}{14} \\
\hline & 1000 & 8 & 6 & 8 & 57.14 & 42.85 & 57.14 & \\
\hline \multirow{2}{*}{$\begin{array}{l}\text { Aspergillus } \\
\text { niger }\end{array}$} & 500 & 7 & 5 & 6 & 43.75 & 31.25 & 37.5 & \multirow[t]{2}{*}{16} \\
\hline & 1000 & 9 & 7 & 8 & 56.25 & 43.75 & 50.00 & \\
\hline
\end{tabular}

\section{Discussion}

Three different crude extracts (ethanol, nhexane and aqueous) of Forsskaolea tenacissima (leaves) were used in this study. These extracts were then tested for their antibacterial and antifungal activity against gram positive and gram negative bacteria.

The results revealed that; the n-hexane extract of leaves of Forsskaolea tenacissima showed tremendous activity against Staphylococcus aureus at higher concentration. The data was recorded as $12 \mathrm{~mm}(80 \% \mathrm{ZI})$ at the concentration of 1000 $\mu \mathrm{g} / \mathrm{ml}$. The lowest data was recorded by aqueous extract at the concentration of 500 $\mu \mathrm{g} / \mathrm{ml}$. The best result was recorded by $\mathrm{n}-$ hexane extract when tested against Bacillus subtilis. It showed $10 \mathrm{~mm}(71.42 \% \mathrm{ZI})$ at the concentration of $1000 \mu \mathrm{g} / \mathrm{ml}$. A study investigated the antimicrobial activity of Forsskaolea tenacissima against Staphylococcus aureus which showed maximum ZI of 14mm [28]. In another study authors also investigated the antimicrobial activity of ethanol extracted samples of Forsskaolea tenacissima (Aril parts) against Klebsiella pneumonia by disc diffusion method and measured ZI of 2.0 and $4.3 \mathrm{~mm}$ [18]. While Owolabi and his co-authors found no antimicrobial activity against Staphylococcus aureus and Bacillus subtilis using ethanol extract of Forsskaolea tenacissima (leaves) at any concentration [21]. In another study, authors investigated the antimicrobial activity of ethanol extracted sample of Forsskaolea tenacissima and 
observed about $6 \mathrm{~mm}$ ZI against $S$. auerus, 8 $\mathrm{mm}$ ZI against Staphylococcus faecolis and $4 \mathrm{~mm}$ ZI against Bacillus subtilis, respectively [1].

Aqueous extract showed highest inhibition against Xanthomonas maltophilia and E. coli at both the concentrations, as compared to nhexane and ethanol. While Clavibacter michiganense was highly sensitive to ethanol extract as compared to other extracts. Authors studied the antimicrobial activity of methanol extract sample of Forsskaolea tenacissima $\mathrm{L}$. which showed optimum zone of inhibition of $5 \mathrm{~mm}$ and $6 \mathrm{~mm}$ against Pseudomonas aeruginosa and $12 \mathrm{~mm}$ against E. coli, respectively [22]. In another study authors also investigated the aqueous extracted sample of Forsskaolea tenacissima L. and observed effective results against gram positive bacteria [4]. The obtained results of antimicrobial activity of Urtica dioica (leaves, stem) and observed that ethanol extract showed significant antimicrobial activity against different human pathogens [29]. In another study, the antimicrobial activity of n-hexane extracted sample of Forsskaolea tenacissima L by disc diffusion method was studied and observed that $n$-hexane extracted sample was effective against Gram negative bacteria. Antimicrobial activity of Forsskaolea tenacissima of n-hexane extracted sample against Streptococcus mutants with significant result of $5 \mu \mathrm{g} / \mathrm{ml}$ minimum inhibitory concentration, n-hexane extracted sample of Forsskaolea tenacissima L. against clinical isolate which exhibit good activity 5 $\mu \mathrm{g} / \mathrm{ml}$ minimum inhibitory concentrations (MIC) against all the tested clinical isolates [30]. In this study authors investigated the antimicrobial activity of n-hexane and aqueous extracted sample of Urtica dioica against Staphylococcus aureus strain which showed little antimicrobial activity against all tested Staphylococcus strain [24].
N-hexane extracted sample of Forsskaolea tenacissima (leaves) also showed maximum zone of inhibition against all tested bacteria. Ethanol extract showed best result against Clavibacter michiganense As, 12mm (75\% ZI) at higher concentration, while against Acromonium alternatum aqueous extract showed the highest inhibition of $9 \mathrm{~mm}(75 \%$ ZI). In this study the authors investigated the antimicrobial activity of n-hexane extracted sample of Urtica dioica, which showed maximum zone of inhibition against gram positive bacteria [31]. Another study was conducted to observe the antimicrobial activity of leaf, stem and root extracts of ethyl acetate against Xanthomonas malvacearum bacteria. The ethyl acetate showed activity with $500 \mu \mathrm{g} / \mathrm{ml}$ more than the pure antibiotic [31]. Against Rhizopus stolinifer aqueous extract showed the highest ZI at both the concentration, while against Trichoderma reesei, highest ZI was recorded by Ethanol and aqueous extracts, which were recorded as $8 \mathrm{~mm}(57.14 \% \mathrm{ZI})$ at the concentration of $1000 \mu \mathrm{g} / \mathrm{ml}$. Ethanol extract showed highest ZI against Aspergillus niger at both the concentration as compared to other extracts.

\section{Conclusion}

N-hexane extract showed tremendous activity of $12 \mathrm{~mm}(80.00 \% \quad \mathrm{ZI})$ against Staphylococcus aureus, while ethanol extract showed $12 \mathrm{~mm} \quad(75.00 \% \quad$ ZI) against Clavibacter michiganense at higher concentration $1000 \mu \mathrm{g} / \mathrm{ml}$, respectively.

\section{Authors' contributions}

Conceived and designed the experiments: Z Li \& SS Shah, Performed the experiments: T Aslam \& SS Shah, Analyzed the data: S Ahmed, N Hassan \& S Hussain, Contributed materials/ analysis/ tools: Z Li \& M Peng, Wrote the paper: SS Shah \& T Aslam.

\section{Acknowledgments}

This work was supported by The National Program on Key Basic Research Project (2015CB150801), Key Science and Technology Program of Jilin Province 
(2012ZDGG008), and Jilin Province Science and Technology Development Plan Project (20170414051GH).

\section{References}

1. Prusti A, Mishra SR, Sahoo S \& Mishra SK (2008). Antibacterial activity of some Indian medicinal plants. Ethnobotanical Leaflets 12: 227-230.

2. Silver L \& Bostian K (1993). Discovery and development of new antibiotics: the problem of antibiotic resistance. Antimicrobial Agents and Chemotherapy 37(3): 377-383.

3. Organization WH (2008). Traditional Medicine Fact sheet No. 134.

4. Srinivasan D, Nathan S, Suresh $T$ \& Perumalsamy PL (2001). Antimicrobial activity of certain Indian medicinal plants used in folkloric medicine. Journal of Ethnopharmacology 74(3): 217-220.

5. Hancock RE., Nijnik A, \& Philpott DJ (2012). Modulating immunity as a therapy for bacterial infections. Nature Reviews Microbiology 10(4): 243-254.

6. Dionisi HM, Lozada M \& Olivera NL (2012). Bioprospection of marine microorganisms: biotechnological applications and methods. Revista Argentina De Microbiología 44(1): 49-60.

7. Peterson LR \& Dalhoff A (2004). Towards targeted prescribing: will the cure for antimicrobial resistance be specific, directed therapy through improved diagnostic testing. Journal of Antimicrobial Chemotherapy 53(6): 902905.

8. Lanfranco G (1999). Invited review article on traditional medicine. Electronic Journal of Biotechnology 2: 1-3.

9. Daniel, AD., Sylvia U \& Ute R, (2012). A Historical Overview of Natural Products in Drug Discovery. Metabolites 2(2): 303336.

10. Mainasara MM., Aliero BL, Aliero AA \& Dahiru SS (2011). Phytochemical and antibacterial properties of Calotropis procera (Ait) R. Br.(Sodom Apple) fruit and bark extracts. International Journal of Modern Botany 1(1): 8-11.

11. Abebe D, Debella A \& Urga K (2003). Medicinal plants and other useful plants of Ethiopia.

12. Cassidy A, Hanley B, \& LamuelaRaventos RM (2000). Isoflavones, lignans and stilbenes-origins, metabolism and potential importance to human health. Journal of the Science of Food and Agriculture 80(7): 1044-1062.

13. Baytop $\mathrm{T}$ (1999). Therapy with medicinal plants in Turkey (Past and Present), $2^{\text {nd }}$ Edition Istanbul, Nobel Tip Basimevi 169.

14. Shinwari ZK (2010). Medicinal plants research in Pakistan. Journal of medicinal plants research 4(3): 161-176.

15. Sher H, Al-Yemeni M, \& Sher H (2010). Forest resource utilization assessment for economic development of rural community in northern parts of Pakistan. Journal of Medicinal Plants Research 4(17): 1786-1789.

16. Sher H, Alyemeni M, Wijaya L \& Shah AJ (2010). Ethnopharmaceutically important medicinal plants and its utilization in traditional system of medicine, observation from the Northern Parts of Pakistan. Journal of Medicinal Plants Research 4(18): 1853-1864.

17. Shinwari ZK \& Qaiser M. (2011). Efforts on conservation and sustainable use of medicinal plants of Pakistan. Pakistan journal of botany 43(1): 5-10.

18. Nweze E, Okafor J \& Njoku O (2004). Antimicrobial activities of methanolic extracts of Trema guineensis (Schumm and Thorn) and Morinda lucida benth used in Nigerian. Bio-research 2(1): 3946.

19. Shah P (2005). The need for new therapeutic agents: what is in the pipeline?. Clinical Microbiology and Infection 11(s3): 36-42. 
20. Özcan M (2005). Mineral composition of different parts of Capparis ovata Desf. var. canescens (Coss.) Heywood growing wild in Turkey. Journal of Medicinal Food 8(3): 405-407.

21. Owolabi OJ, Omogbai EK \& Obasuyi O (2007). Antifungal and antibacterial activities of the ethanolic and aqueous extract of Kigelia africana (Bignoniaceae) stem bark. African Journal of Biotechnology 6(14): 16771680.

22. Shahid W, Durrani R, Iram S, Durrani M \& Khan FA (2013). Antibacterial activity in vitro of medicinal plants. Sky Journal of Microbiology Research 1(2): 5-21.

23. Besnard G, Christin PA, Male PG, Coissac E, Ralimanana H \& vorontsova MS (2013). Phylogenomics and taxonomy of Lecomtelleae (Poaceae), an isolated panicoid lineage from Madagascar. Annals of Botany 112(6): 1057-1066.

24. Jagetia GC, Shirwaikar A, Rao SK \& Bhilegaonkar PM (2003). Evaluation of the radioprotective effect of Ageratum conyzoides Linn. extract in mice exposed to different doses of gamma radiation. Journal of Pharmacy and Pharmacology 55(8): 1151-1158.

25. Ayyanar M. \& Ignacimuthu S (2011). Ethnobotanical survey of medicinal plants commonly used by Kani tribals in Tirunelveli hills of Western Ghats, India. Journal of Ethnopharmacology 134(3): 851-864.
26. Choudhary K, Singh M \& Pillai U (2008). Ethnobotanical survey of Rajasthan-An update. AmericanEurasian Journal of Botany 1(2): 38-45.

27. Ren W, Qiao Z, Wang H, Zhu L \& Zhang L (2003). Flavonoids: promising anticancer agents. Medicinal Research Reviews 23(4): 519-534.

28. Negi BS \& Dave BP (2010). In Vitro antimicrobial activity of Acacia catechu and its phytochemical analysis. Indian Journal of Microbiology 50(4): 369-374.

29. Fattahi S, Zabihi E, Abedian Z, Pourbagher R, Ardekani AM, Mostafazadeh A \& Akhavan-Niaki $\mathrm{H}$ (2014). Total phenolic and flavonoid contents of aqueous extract of stinging nettle and in vitro antiproliferative effect on hela and BT-474 Cell lines. International Journal of Molecular and Cellular Medicine 3(2): 102-107.

30. Hashem M, Alamri SA, Shathan AA, Alrumman SA, Moustafa MFM (2013). Antibacterial Behavior of Weed Plants from Aseer, Saudi Arabia and Their Possible Mode of Action. International Journal of Science and Research 4(11): 2490-2499.

31. Kukrić ZZ, Topalić-Trivunović LN, Kukavica BM, Matoš SB, Pavičić SS, Boroja MM, Savić AV (2012). Characterization of antioxidant and antimicrobial activities of nettle leaves (Urtica dioica L.). Acta Periodica Technologica (43): 257-272. 